\title{
VYBRANÉ GEOGRAFICKÉ ASPEKTY VÝVOJA LAZNÍCKEJ KRAJINY K. Ú. HRUŠOV
}

Ján Lacika, Ján Hanušin

\begin{abstract}
This contribution has been created as a part of the scientific project focused on the geographical research of the specific type of the cultural landscape characterized by scattered settlement. This type of landscape covers almost one tenth of the Slovakia territory. Landscape with scattered settlement has developed previously in the montane regions of the Slovak Carpathians characterized by hindered live condition of the inhabitants closely connected to nature. Therefore, these regions have been distinguished by very sparse settlement. Local governments of the villages with scattered settlements have lacked for defaults of inner human, material and financial sources for management of the landscape with high operating costs. They need helps from outside. This research project has been an example of successful co-operation geographers with active local government of the village Hrušov (district Vel'ký Krtiš) on the project of the revitalisation of landscape with scattered settlement.
\end{abstract}

Keywords: geography, scattered settlement, cultural landscape, Hrušov, Krupinská Planina Plateau

\section{Úvod}

Lazy, kopanice či štále sú fenomén kultúrne aj historicky úzko spätý so Slovenskom. Tradičná kultúrna krajina s rozptýleným typom osídlenia zaberá až takmer desatinu rozlohy Slovenskej republiky (Verešík, 1974). Vyvinula sa však najmä v horských oblastiach so st’aženými podmienkami na život, preto je riedko osídlená. Trvalo ju obýva ju len nepatrné množstvo l’udí, rádovo niekol'ko tisíc obyvatel'ov. Navyše možno dlhodobo pozorovat' odliv prevažne mladých l'udí, st'ahovanie lazníkov v produktívnom veku v lepšom prípade do dediny pri lazoch, častejšie však celkom preč $\mathrm{z}$ regiónu do rozvinutejších kútov Slovenska s lepšími príležitost’ami na prácu. Laznícka populácia redne a navyše aj starne, čo má nežiadúci negatívny dopad na stav tradičnej lazníckej krajiny. Hospodársky málo rozvinuté oblasti s rozptýleným osídlením nedisponujú vnútornými l’udskými, materiálnymi a kapitálovými zdrojmi na obhospodarovanie tohto prevádzkovo vel'mi nákladného typu kultúrnej krajiny. Pomocná ruka musí príst' zvonku. Malebná slovenská laznícka krajina je právom považovaná za významné kultúrne dedičstvo Slovenska, preto je $\mathrm{v}$ celospoločenskom záujme vytvárat' projekty zamerané na jej záchranu a zvel'ad'ovanie opierajúce sa o výsledky komplexného výskumu krajiny. 
Na juhu Krupinskej planiny leží typická laznícka obec Hrušov (okr. Vel'ký Krtíš), kde sa aj vd'aka agilnej samospráve darí ako-tak udržiavat' tradičnú podobu lazov v chotári ale aj v zástavby kompaktnej dediny. Tento príspevok je súčastou projektu zameraného na geografický výskum historickej kultúrnej krajiny k. ú. Hrušov $\mathrm{s}$ rozptýleným osídlením vyznačujúcim sa s viacerými lokálnymi špecifikami. Prezentuje výsledky skúmania d’alších aspektov transformácie lazníckej krajiny obce, ktoré neboli predmetom predchádzajúcich príspevkov autorov článku (Hanušin, Lacika, 2017, 2018, Lacika, Hanušin, 2018.). Zamerali sme sa na aspekty týkajúce sa najmä geografie sídel a l'udové stavitel'stvo.

\section{Teoreticko-metodické východiská}

Rozptýlené osídlenie je fenomén $\mathrm{v}$ centre osobnosti nielen urbanistov, architektov, historikov, etnológov či sociológov. Z hl'adiska toho, že sa vyvíja $\mathrm{v}$ priestore a čase, majú do tohto výskumu čo povedat' aj geografi so svojimi nástrojmi a metódami zameranými na komplexný a integrovaný výskum krajinu. Tradičné ale nezastupitel'né miesto $\mathrm{v}$ tomto výskume má detailná práca $\mathrm{v}$ teréne konfrontujúca zozbierané údaje a dáta textovej, grafickej a kartografickej podobe. V našom prípade sa osvedčila aj metóda spracovania údajov tzv. kolektívnej pamäti, z ktorou úspešne pracujú najmä etnológovia. V prípade predmetného územia obce Hrušov je táto kolektívna pamät' hlboko vžitá a uchovávaná, a preto dobre vedecky uchopitel'ná. Svedectvá generácií miestnych l'udí prenášaných ústnym podaním sú cenným zdrojom informácií o niekdajšej podobe krajiny tejto hontianskej obce a vhodne dopĺñajú obraz o jej vývoji získaný inými exaktnejšími metódami výskumu. Využili sme poznatky autentických svedectiev Hrušovčanov získané etnológom J. Botíkom $(1980,2014)$ ale aj vlastnými riadenými rozhovormi $\mathrm{s}$ miestnymi znalcami obce a regiónu (v spolupráci $\mathrm{s}$ V. Irom). V prípade obce Hrušov sme sa mohli opierat' aj o výdatnú podporu miestnej samosprávy, ktorá z vlastnej iniciatívy viedla historický a etnografický výskum obce Hrušov a prezentovala ho v 6-dielnej knižnej edícii s názvom Tradičná l’udová kultúra obce Hrušov, ktorá na Slovensku nemá obdobu. Pre poznávanie historickej kultúrnej krajiny predmetného územia bola vel'mi dobre použitel'ná metóda komparácií dostupných historických máp so súčasným stavom krajiny identifikovaným detailným terénnym výskumom. Pracovali sme najmä s mapami viacnásobného vojenského mapovania niekdajšieho Uhorska prístupné na Národnom Geoportáli SR (2014), poslúžili nám aj novšie kartografické podklady, k dispozícii sme mali aj letecké snímky predmetného územia.

\section{Laznícka krajina na Slovensku}

Laznícka krajina je osobitým typom kultúrnej krajiny, ktorej hlavnou črtou je prítomnost' rozptýleného osídlenia a naň nadväzujúci špecifický spôsob 
obhospodarovania územia. Človek a príroda tu vytvorili špecifický systém väzieb, sformovali kultúrnu krajinu s nízkou mierou pretvorenia pôvodnej prírodnej krajiny. Krajinu s rozptýleným osídlením možno $\mathrm{z}$ hl'adiska gradientu zmien (Forman a Gordon, 1993) považovat' za územie s najnižším stupňom premeny obrábanej krajiny. Podl'a Hubu (1989) tomto type krajiny dochádza k špecifickej syntéze sídelnej a pol'nohospodárskej funkcie krajiny formujúcej sa v marginálnych podmienkach, $\mathrm{v}$ ktorých je sídelný prejav extrémny a núdzový. V minulosti boli rozptýlené sídla spoločensky izolované a energeticky a hmotne značne sebestačné. V nových ekonomických spoločenských podmienkach dneška sa táto izolovanost' a sebestačnost' stráca a aj vd'aka skvalitňovaniu dostupnosti a civilizačným vymoženostiam stáli alebo občasní obyvatelia rozptýlených sídel sa vyrovnávajú životnou úrovňou a komfortom bývania obyvatel’om kompaktných sídel.

Je pravdepodobné, že roztratené typy sídel vznikali v na území chotára Hrušova už v stredoveku., avšak k väčšiemu rozmachu lazníckeho spôsobu života a využívania krajiny došlo až po zavedení Lesného poriadku Maximiliána II. Habsburského (Constitutio Maximiliano) v roku 1565 (Lacika, 2009). Cisárske opatrenie zabraňovalo ničeniu lesov valaskými pastiermi, ktorí boli nútení zanechat' tradičné košiarové pastierstvo, začat' si stavat' stále sídla a venovat' sa viac rol'níctvu. $\mathrm{V}$ priebehu 16. storočia $\mathrm{v}$ slovenských Karpatoch prebiehala druhá fáza valašskej kolonizácie nazývaná aj kopaničiarska kolonizácia. V rámci nej dochádzalo k masívnejšiemu dosídlovaniu riedko osídlených horských oblastí s drsnejšími prírodnými podmienkami. Okrem typických horských sídel, akým je napríklad Ždiar alebo Osturňa, vtedy vzniklo aj mnoho roztratených sídel založených priamo na grunte. Druhá vlna početnejšieho zakladania lazov, kopaníc a štálov v slovenských Karpatoch nastala po roku 1869 . Vyvolalo ju uplatňovanie komasácie, štátom riadeného procesu scel'ovania pozemkov, ktorý sebou niesol nielen vznik nových roztratených sídel ale aj výrazné zmeny v charaktere krajinnej pokrývky.

Podmienky pre normálne udržiavanie lazníckeho spôsobu života zotrvávali na Slovensku až do druhej polovice 20. storočia. Socialistická premena vidieka spojená s masívnou kolektivizáciou priniesla lazom a lazníkom radikálnu zmenu, ktorá sa stala ich vážnou hrozbou. Podl'a Verešíka (1974) bolo v roku 1961 na Slovensku takmer 2900 roztratených sídel patriacich do chotára 166 obcí a žilo v nich približne 140000 obyvatel’ov. Podobný počet lazníkov uvádza aj Spišiak (1998) v roku 1991. V nových politických a spoločenských pomeroch po novembri 1989 možno pozorovat' odliv pôvodného lazníckeho obyvatel'stva, ktoré bolo len sčasti nahradené chalupármi využívajúcimi laznícke obydlia občasne na rekreáciu. Hrušov je príkladom lazníckej obce, kde možno pozorovat' zatial' len sporadický prílev tzv. novousadlíkov, často prichádzajúcich na lazy z čisto mestského prostredia. Do určitej miery tomuto trendu pomáha popularita Hrušova v očiach verejnosti pre ich úspešné organizovanie vel'kého folklórneho festivalu Hontianska paráda. V roku 2018 sa konal už 23. ročník. 


\section{Predmetné územie}

Za modelové sme si vybrali katastrálne územie obce Hrušov v okrese Vel'ký Krtíš (mapa 1) s rozlohou 2331 ha. Z viacerých aspektov môžeme jeho polohu za periférnu resp. hraničnú. Katastrálne územie leží na južnom okraji Krupinskej planiny, pomerne blízko jej hranice s Ipel'skou kotlinou. Severná čast' chotára zasahuje na územie nekrasovej Dačolomskej planiny, rozlohou väčšia južná čast' patrí do podcelku Modrokamenské úboče. Prítomnost' tých dvoch kontrastných geomorfologických prostredí sa odráža v členení predmetného územia do dvoch typov prírodnej krajiny - plošinového a úbočového (Lacika, Hanušin, 2018). Z geologického hladiska je predmetné územie pomerne homogénne, v podloží celého chotára sa nachádzajú horniny vulkanického komplexu vytvoreného neogénnym vulkanizmom. Štruktúrne a litologické vlastnosti tých hornín sú priaznivé na híbenie kamenných pivníc zhlukujúcich do troch lokalít $\mathrm{v}$ rámci intravilánu obec. Vlastnosti ostatných zložiek prírodnej krajiny sú determinované meniacim geomorfologickým prostredím $\mathrm{v}$ rámci katastrálneho územia $\mathrm{v}$ obci.

Mapa 1: Poloha modelového územia

Map 1: Position of the model area

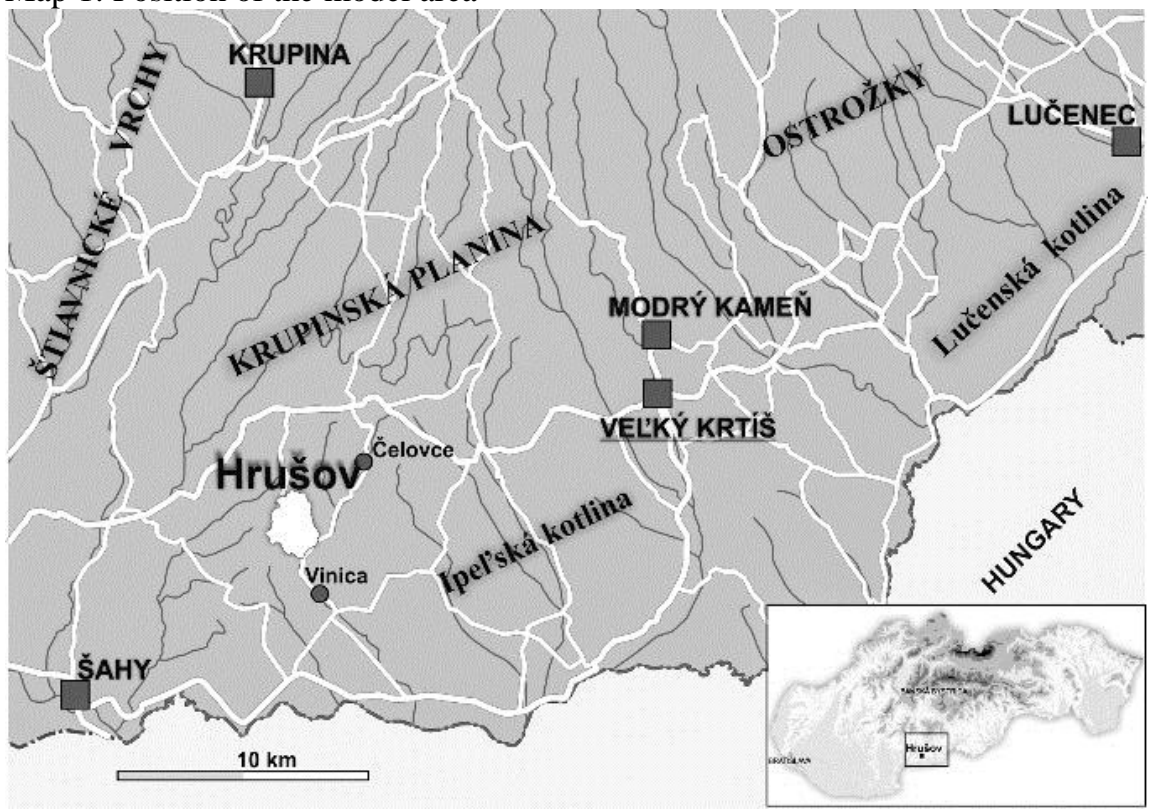

Periférnost' polohy k. ú. Hrušova je markantná aj z kultúrno-historického a ekonomického aspektu. Už pred rokom 1918 mal Hrušov ako súčast' 
niekdajšieho Uhorska okrajovú polohu na okraji Hontianskej župy, bol pomerne vzdialený od regionálnych centier. Rozpadom monarchie sa táto marginalita ešte zvýraznila. Hrušov stratil výhodu relatívne dobrej dostupnosti metropolitnej Budapešti a v novom štáte sa začlenil do dlhodobo zanedbávaného a hospodársky nepodporovaného regiónu na juhu stredného Slovenska. Periférna poloha a nízky stupeň hospodárskeho rozvoja regiónu zapríčiňujú, že obec Hrušov sa vyl'udňuje. Z 1200 obyvatel'ov v roku 1970 klesol počet obyvatel'ov na 849 v roku 2016.

\section{Stav poznania}

V rámci výskumu lazníckej krajiny na Slovensku sú identifikovatel’né dve skupiny vedcov, najviac sa jej venovali etnológovia a geografi. Priekopníkmi tohto segmentu geografického výskumu sú napr. Janšák (1929) a Hromádka (1943), geografickým aspektom rozptýleného osídlenia sa venovali aj Verešík (1974), Lukniš (1980), Huba (1989, 1990, 1997), Lauko (1985), Spišiak (1998), Petrovič (2005 a 2006) a Omasta (2011). Rozptýlené sídla na Slovensku boli aj v centre pozornosti Švecovej $(1979,1980,1984,1988)$, Botíka (1980) a d'alších etnológov.

Rozsah prác z oblasti regionálneho výskumu krajiny Hrušova a jeho obyvatel'ov je pozoruhodne vel'ký. Táto rázovitá a v mnohých aspektoch vel'mi osobitá obec sa teší pozornosti najmä etnológov a geografov. Z iniciatívy miestnej samosprávy vznikla unikátna knižná edícia Tradičná l’udová kultúra obce Hrušov zameraná predovšetkým na l'udové zvyky a umenie Hrušovčanov a l'udové stavitel'stvo. V autorskom kolektíve edície je renomovaný etnológ J. Botík ako aj lokálni znalci Hrušova P. Brada, J. Brloš, A. Brlošová a A. Sásová. V rokoch 2010 až 2017 vydali postupne 8 hodnotných monografí́. Okrem toho vznikla štúdia Zrníkovej a Hrčkovej (2012) zaoberajúca sa výskumom historických krajinných štruktúr v katastroch Hriňovej a Hrušova. Geografickými aspektmi lazníckej krajiny Hrušova sa venovali Hanušin a Lacika $(2017,2018)$ a Lacika a Hanušin (2018).

\section{Kultúrna krajina}

\section{Vývoj kultúrnej krajiny v extraviláne}

Charakteristika kultúrnej krajiny predmetného územia spred 18. storočia môže byt' len hypotetická, pretože sa opiera len o nepriame archeologické indície a sporé historické listinné pramene. Dá sa predpokladat', že premena prírodnej krajiny na kultúrnu sa tu začala už v neolite a intenzívnejšiu podobu nadobudla od doby bronzovej. Je známe, že predstavitelia viacerých kultúr žijúcich na Slovensku od praveku až po stredovek sa nevyhýbali výšinným polohám a stavali na nich svoje opevnené hradiská. Z tohto aspektu mohol byt' planinový typ krajiny Hrušova na osídlenie a hospodárske využívanie atraktívny. Aktérmi prvých zmien 
prírodnej krajiny mohli byt' pastieri a rol’níci, po ktorých sa v lokalite Zabukovina našli orbou obnažené archeologické artefakty sídliska bádenskej kultúry z obdobia eneolitu (Brada a Brloš, 2013). Na zaujímavý indikátor zmien krajinnej pokrývky poukázal Botík (2014). V hrušovskom chotári identifikoval viacero chotárnych názvov (Holizeň, Čert’až, Čertenia, Žiar) viažucich sa na starobylé spôsoby získavania pôdy klčovaním a vypal'ovaním lesa. Tieto názvy vypovedajú o týchto transformačných procesoch ale ich presnejšie nedatujú. $Z$ toho, že ide o názvy slovanského pôvodu možno usudzovat' len to, že určite nevznikli pred príchodom starých Slovanov). Niektoré z týchto názvov nachádzame na mape 2. vojenského mapovania z prvej polovice 19. storočia.

Mapa 2: Chotár Hrušova na mape 1. vojenského mapovania Uhorska (1764 1787) a identifikované prvky historickej kultúrnej krajiny

Map 2: The cadastral area of the village of Hrušov on the map of $1^{\text {st }}$ Military Mapping of ancient Hungary (1764 - 1787) and identified elements of the historical cultural landscape
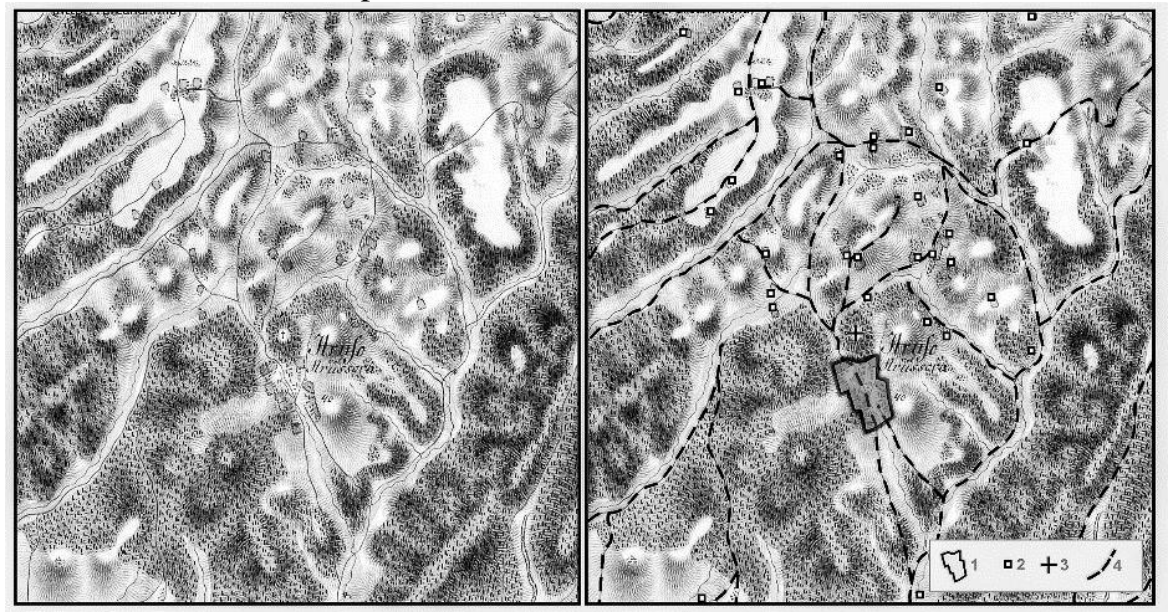

Zdroj: Národný Geoportál SR (2014)

Najstaršie historické pramene týkajúce sa predmetného územia sú z 13. storočia, sú však natol'ko strohé, že z nich nedá vyčítat' ako v tom čase vyzerala kultúrna krajina. Možno predpokladat', že plošinová čast' chotára bola v stredoveku intenzívnejšie osídlená a obhospodarovaná, jestvovalo tu dokonca kompaktné sídlo s názvom Japronc, pravdepodobne na mieste lazníckeho sídla Jablonec. Zaniklo ešte počas stredoveku. Lepšiu výpovednú hodnotu majú historické listiny uvádzajúce súpisy majetku, osôb a domov a archívne údaje o miestnej samospráve a remeslách. Najstaršia je z roku 1635. Z týchto prameňov sa dá dedukovat' miera 
exploatácie krajiny v chotári. Od druhej polovice 18. storočia máme $\mathrm{k}$ dispozícii aj vel'mi cenné zdroje informácií v kartografickej podobe. Hrušov sa objavuje na historických mapách všetkých troch vojenských mapovaní habsburskej monarchie dostupné na Národnom Geoportáli (2014). Mapa 1. vojenského mapovania z 2. polovice 18. storočia (mapa 2) zachytáva zárodok dnešnej lazníckej kultúrnej krajiny. Sú v nej zakreslené chotárne sídla a cesty vedúce knim. Nie sú pomenované, ale podl'a polohy korešpondujú s niektorými súčasnými lazmi. Niekol'ko dodnes používaných chotárnych názvov sídel v extraviláne Hrušova však nachádzame na mape 2. vojenského mapovania (mapa 3A) z prvej polovice 19. storočia.

Mapa 3: Chotár (A) a intravilán (B) Hrušova na mape 2. vojenského mapovania Uhorska (1810 - 1769). 1 - intravilán, 2 - cesta

Map 3: The cadastral area (A) and residential area (B) of the village of Hrušov on the map of $1^{\text {st }}$ Military Mapping of ancient Hungary (1764 - 1787). 1 - residential area, 2 - road

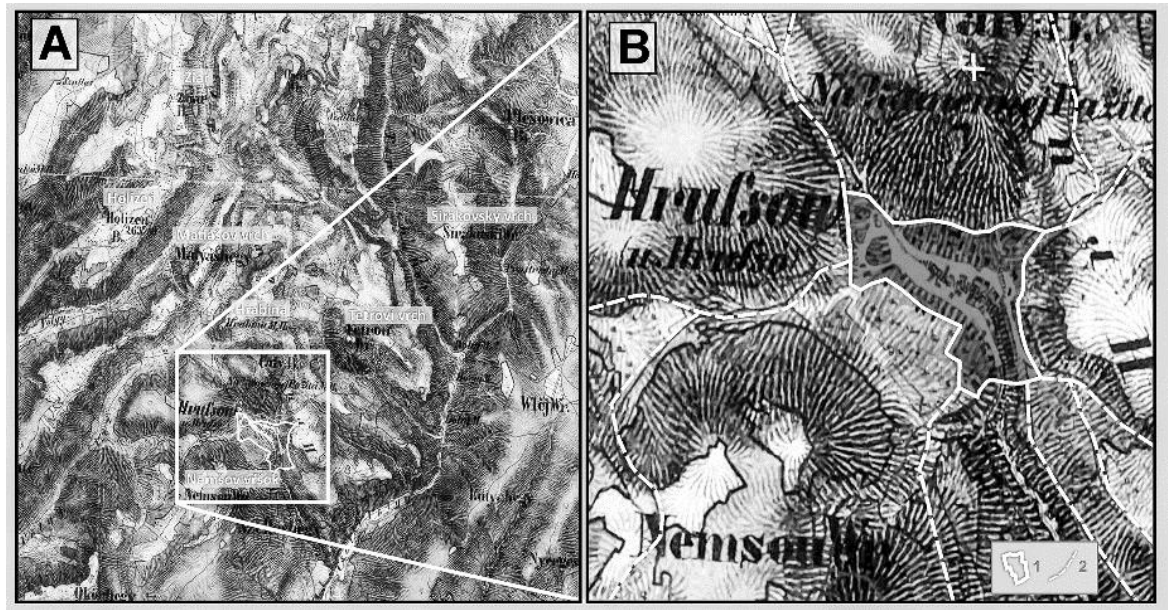

Zdroj: Národný Geoportál SR (2014)

Podl’a Botíka (2014) sa zárodky lazníckej krajiny v chotári Hrušova mohli utvárat' už pred 18. storočím. Vychádzajúc z poznatkov získaných vd’aka kolektívnej pamäti Hrušovčanov, ktorá je dodnes živou nepísanou kronikou obce. Podl'a pamätníkov bolo v 2. polovici 19. storočia najmenej 10 hrušovských rodín s hospodárskymi objektmi postavenými mimo intravilán obce. Prvé objekty v extraviláne mali čisto hospodársku funkciu. Pôvodne slúžili na sezónny chov dobytka a oviec ako pajta (stodola) alebo staja (maštal'). Ich počet markantne narástol po komasácii uskutočnenej v roku 1869. Hospodárske objekty v otvorenej krajine sa postupne začali transformovat' na sezónne obydlia, prvotné laznícke 
usadlosti. Švecová (1984) uvádza, že na prelome 19. a 20. storočia ich v Hrušovskom chotári boli približne 30. Novým impulzom pre zakladanie lazníckych sídel bola parcelácia cirkevnej a vel'kostatkárskej pôdy ukončená v roku 1914 umožňujúca aj pre chudobnejším rol’níkom získat pôdu. Okrem rapídneho zvyšovania počtu chotárnych sídel sa čoraz viac z nich transformovala na celoročne obývané sídlo. Botík (2014) si všimol, že v rokoch 1910 až 1921 sa počet obyvatel'ov menil len nepatrne, zato rapídne narástol počet domov. O prírastok do domového fondu obce vel'kou mierou prispelo práve budovanie celoročne obývaných lazníckych usadlostí. Laznícky spôsob života s ojedinelým dvojrezidenčným bývaním v Hrušove sa udržiaval aj po roku 1948, pretože socialistická kolektivizácia sem dorazila oneskorene. Až to, že v roku 1979 sa miestni jednotlivo hospodáriaci rol’níci pričlenili $\mathrm{kJRD} v \mathrm{v}$ susednej Vinici. Ukončenie dominancie malých rol'níkov a nové pol'nohospodárske technológie (mechanizácia, centralizácia činnosti do výrobných dvorov) prinieslo úpadok lazníctva. Lazy ako vysunuté body obhospodarovania krajiny prakticky stratili svoj význam, mnohé z nich postupne zanikli. Tieto procesy sa postupne prejavili aj na štruktúre pol'nohospodárskej krajiny. Podl'a výskumnej správy Stavoprojektu (Kováčová a kol., 1990) bolo v roku 1990 v k. ú. Hrušova celkom 208 lazníckych sídel s vlastným popisným číslom, v ktorých žilo 413 obyvatel’ov, čo je takmer polovica celej populácie Hrušova.

Výskum realizovaný Stavoprojektom skúmal aj vek lazníckych domov a zistil, že 157 z nich postavili pred rokom 1945. Aj 12 domoch z obdobia rokov 1945 až 1960 budovali podl'a zásad tradičného l'udového stavitel'stva. V prípade väčšiny z 26 domov postavených po roku 1960 už možno pozorovat' odklon od tradičného stavitel'stva. V rámci terénneho výskumu realizovaného v rokoch 2016 až 2018 sme overovali aké zmeny v stave lazníckych sídel nastali od roku 1990. Výsledky výskumu sme zaniesli do mapy (mapa 4). Výskum ukázal, že väčšina lazníckych domov je dodnes v obývatel'nom stave, ich pôvodní obyvatelia a majitelia odst’ahovaní z lazov do dediny, udržiavajú nielen samotnú stavbu ale aj jej okolie. Čast' lazníckych sídel prešlo adaptáciou na rekreačný objekt. Zaznamenali a zmapovali sme prípady masívnejšej modernizácie, ktorá narušila pôvodnú stavebnú podstatu (obr. 1A), pomerne vel'a domov bolo upravených s rešpektovaním pôvodného stavu (obr. 1B). Osobitými prípadmi sú prestavba bývalej stodoly na objekt napodobňujúci l'udové stavitel'stvo (obr. 1C) ale aj úspešný pokus o prinavrátenie autentickej podoby stavby (obr. 1D). 
Mapa 4: Vek a funkčné využitie lazníckych usadlostí v k. ú. obce Hrušov Map 4: The Age and functional utilization of the scattered settlements in the cadastral area of the village of Hrušov

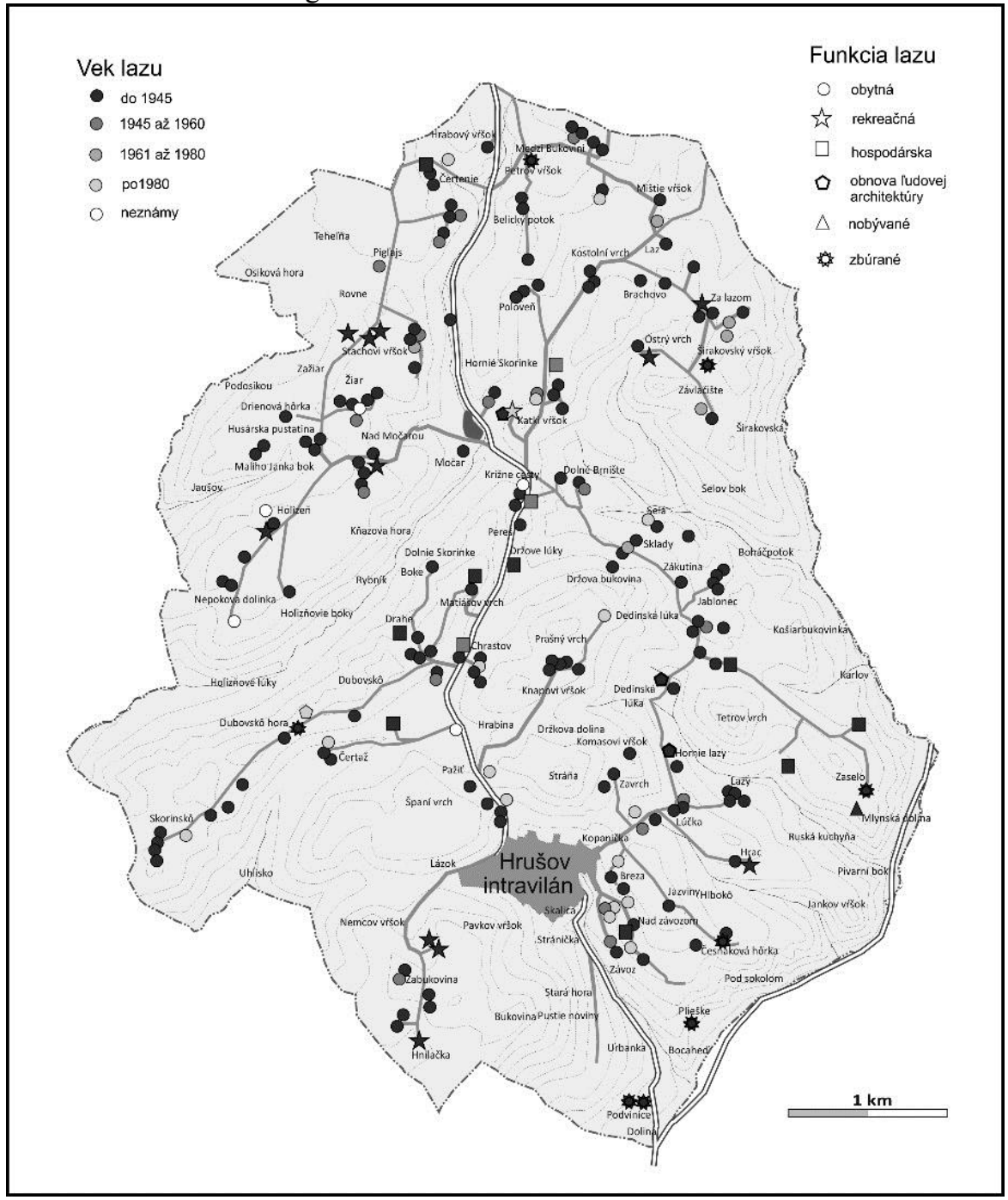


Obr. 1: Typy lazníckych usadlostí v k. ú. Hrušova

Figure 1: Types of scattered settlements
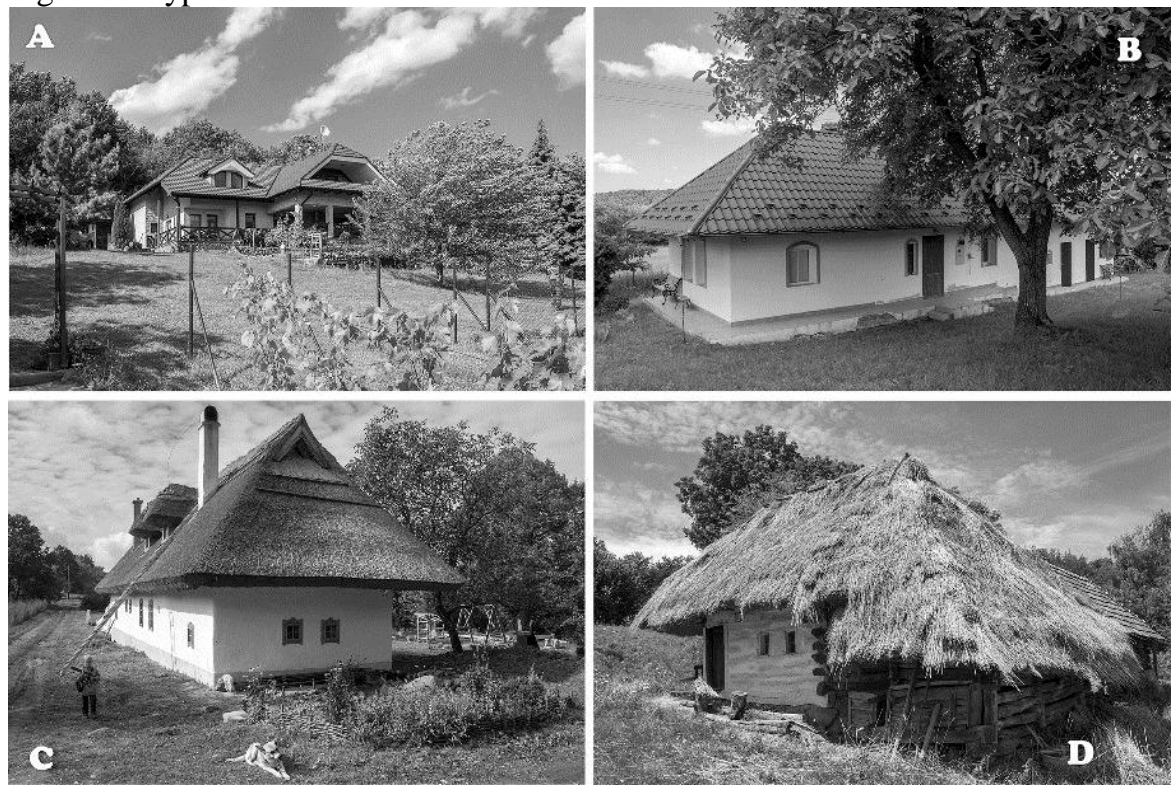

Zdroj: Foto J. Lacika

V článku Laciku a Hanušina (2018) bola preukázané, že priestorové rozloženie lazníckych sídel v chotári Hrušova je do značnej miery determinované premenlivými vlastnostami prírodnej krajiny. Nadväzujúc na tieto výsledky sme sa pokúsili o detailnejší výskum vnútornej kompozície paternu lazov. Identifikovali sme nielen väzbu lazu na kompaktnú dedinu ale aj väzbu na susedné lazy. Mieru odl'ahlosti sme určovali nielen podl'a vzdialenosti od susedov, ale aj podl'a toho, či má daný laz vizuálny kontakt so susednými usadlost’ami. Výsledok je zaznamenaný na mape 5. Zistili sme, že v k. ú. Hrušova jestvujú výrazne izolované laznícke usadlosti vzdialené od susedných viac ako 100 metrov a navyše bez vizuálneho kontaktu. Zároveň sa vyskytujú nápadné zhluky lazníckych usadlostí, ktoré by sa dali označit' ako osady. V zhlukoch sa nachádza blízko seba 4 až 13 domov. Patern niektorých zhlukov lazov prejavuje znaky linearity. Lineárne usporiadanie sa prejavuje v 3 odlišných typoch prírodnej krajiny. Identifikovali sme na pozdĺžnom plošinovom chrbte aj vosi plytkej doliny. V oboch typoch linearity sídla využívajú spoločnú cestu, ktorá ich spája s kompaktnou dedinou. Tretí typ linearity je špecifický, prejavuje sa na hranách planinových plošín, kde najmenej prekážajú obhospodarovaniu pôdy na plošinách. 
Mapa 5: Priestorová kompozícia lazníckych usadlostí v k. ú. obce Hrušov.

Zhlukovanie lazov: 1 - zhluk s počtom lazníckych usadlostí v zhluku, 2 izolovaný laz. Linearita: 1 - v doline, 2 - na plošinovom chrbte, 3 - na hrane plošiny

Map 5: Areal composition of the scattered settlements in the cadastral area of the village of Hrušov.

The clumping of the scattered settlements: 1 - clump of with number of scattered settlements inside of the clump, isolated scattered settlement. The linearity: 1 - in the valley, 2 - on the plateau like ridge, 3 - on the edge of the plateau

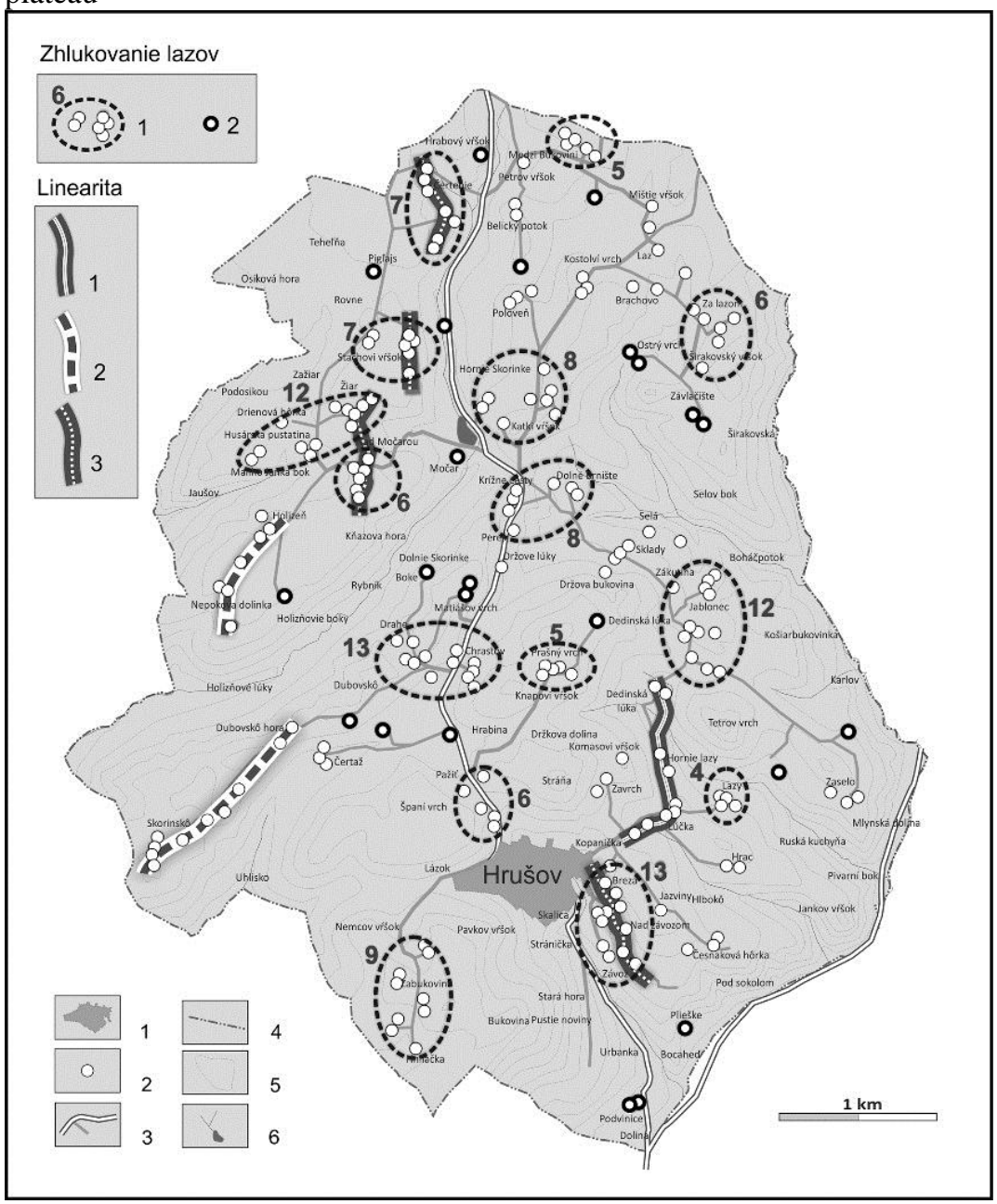




\section{Vývoj kultúrnej krajiny v intraviláne}

V stredoveku boli na území hrušovského chotára dve sídla. Sídlo s názvom Japronc ležiace na plošine planiny identifikoval mad'arský historik Bakács (1971) na historickej mape Hontu spred roku 1526. Toto sídlo dávno zaniklo, zatial' čo stredoveké sídlo Hrusso pretrvalo veky a dnes je z neho kompaktná dedina Hrušov. Jeho lokalizácia do kotlovitého záveru doliny Hrušovského potoka sa ukázala ako vel'mi dobrá. Povaha okolitého terénu umožňovala pomerne l'ahký prístup z dediny k hospodársky využívaným planinovým plošinám na severe a st’ažený prístup do dediny od juhu, odkial' mohli dedinčania najskôr očakávat' útok prípadného nepriatel'a. Na pomerne plochom dne kotlovitého záveru doliny bolo dostatok miesta na vybudovanie dediny s kompaktným intravilánom. Pôdorys tohto sídla zobrazený na historických mapách vojenského mapovania Uhorska (mapy 2 a 3B) sa v podstate dodnes nezmenil. Porovnanie máp z rokov 1935 (mapa 6) a 2018 (mapa 7) ukazuje nízky stupeň transformácie historického jadra Hrušova, ktorý si zachoval nielen pôdorys ale aj väčšinu pôvodnej zástavby. Zmeny nastali mimo tohto jadra. Na mape z roku 1935 ešte nie je zakreslená nová ulica, ktorá sa začala budovat' na mieste bývalých sadov a konopísk v roku 1942 s plánom napojit' ju na tzv. Podunajskú magistrálu. Dnešná cesta 1. triedy č. 75 bola stavaná cez druhú svetovú vojnu z Pláštoviec cez plošiny Krupinskej planiny do Čeboviec, pretože južné prepojenie cez Ipel'skú kotlinu v tom čase patrilo horthyovskému Mad'arsku. K dokončeniu napojenia Hrušova na túto komunikáciu došlo až v roku 1968. Okolo novej ulice oblúkom sa vyhýbajúce historickému jadru obce vznikol nový Hrušov s kultúrnym domom, obecným úradom, obchodom, školou a novou zástavbou rodinných domov.

Mapa 6: Intravilán obce Hrušov v roku 1935

Map 6: Residential area of the village Hrušov in 1935

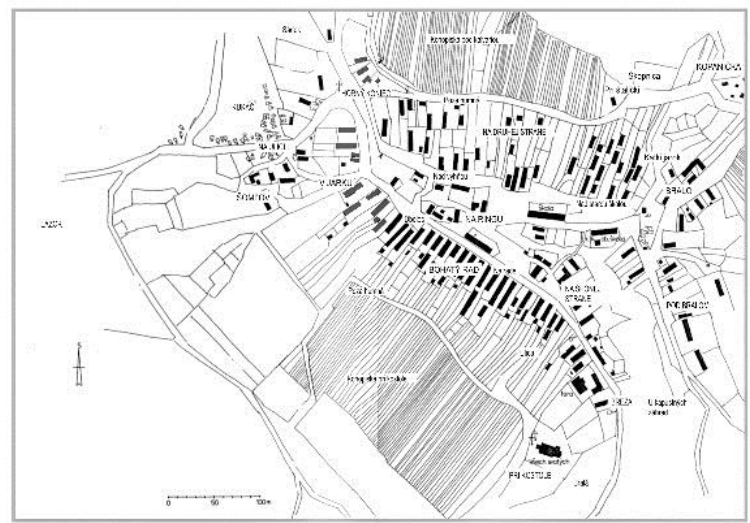

Zdroj: Botík (2014) 
Mapa 7 vznikla terénnym mapovaním intravilánu Hrušova zameraným na charakter jeho zástavby. Domy v intraviláne kompaktnej dediny hromadného typu boli na základe obhliadky a konzultácií s miestnymi obyvatel'mi roztriedené podl'a funkcie a veku. Podl'a kritéria funkcie sme rozlíšili objekty s obytnou funkciou a objekty s hospodárskou alebo kultúrno-spoločenskou funkciou. Podl'a kritéria veku sme identifikovali objekty tradičného typu (postavené zhruba do roku 1970) a objekty moderné (postavené od roku 1970).

Mapa 7: Typológia zástavby intravilánu obce Hrušov v roku 2018

Obytné objekty: 1 - tradičný dom s nepatrnými úpravami, 2 - tradičný dom s výraznejšími úpravami, 3 - moderný dom, 4 - dom v rómskej osade. Objekty s inou ako obytnou funkciou: 1 - tradičný dom, 2 - moderný dom, 3 - drobné hospodárske stavby. Iné značky: 1 - verejná zeleň, 2 - ulica, 3 - chodník, 4 hranica intravilánu

Map 7: Typology of the buildings in the residential area of the village Hrušov in 2018

Building with housing function: 1 - finely adapted traditional house, 2 - highly adapted traditional house, 3 - modern house, 4 - house in Romany colony. Building with other functions: 1 - traditional house, 2 - modern house, 3 change outbuilding. Other marks: 1 - public green area, 2 - street, 3 -pavement, 4 - the residential area boundary

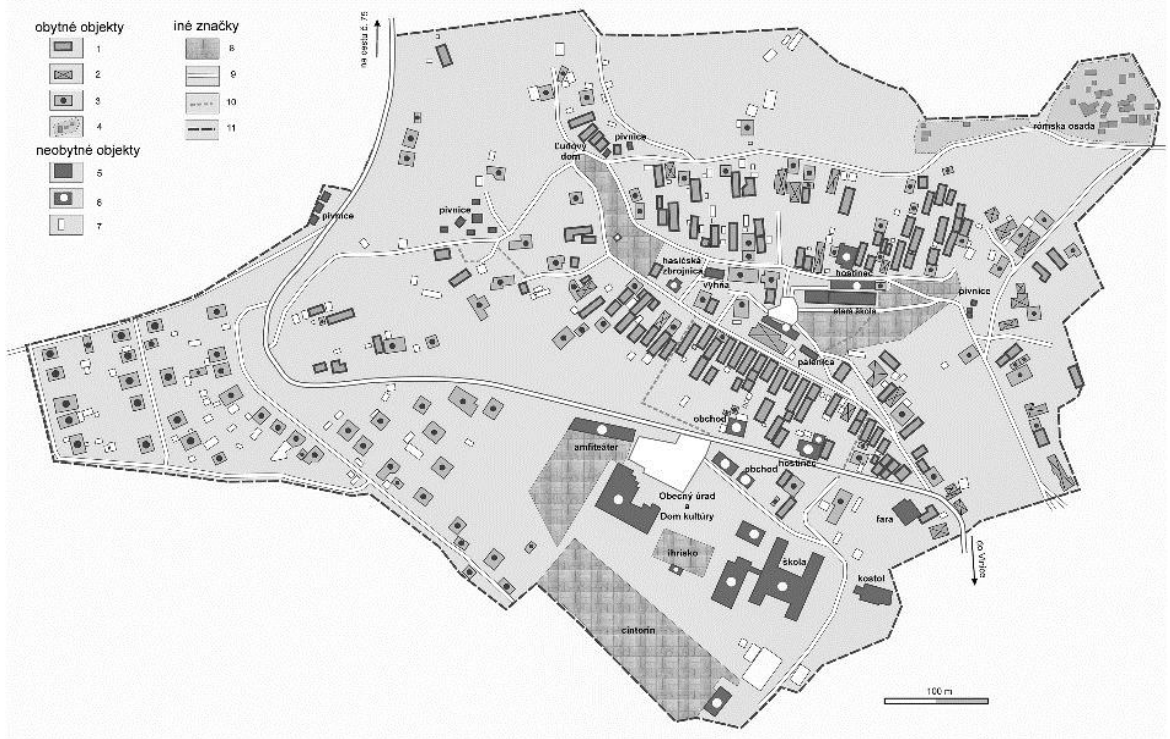


V intraviláne obce sme identifikovali celkom 340 obytných objektov (337 rodinných domov a 3 bytovky). Viac ako polovica rodinných domov v Hrušove má tradičnú podobu s minimálnymi modernizačnými úpravami. V historickom jadre dediny je ich podiel až dvojtretinový. Stavitelia týchto domov nadviazali na tradíciu l'udového stavitel'stva Hontu. Je tu niekol'ko stavieb, ktorý by mali pre svoju výraznú autenticitu byt' zaradené medzi pamiatkovo chránené objekty. Pamiatkovo chránený je iba L’udový dom (č. p. 178) dnes využívaný ako múzeum. $\mathrm{Na} 24$ obytných objektoch v intraviláne obce sa uskutočnili zásadnejšie stavebné úpravy narúšajúce jeho pôvodnú architektúru. Skupina 151 obytných domov je moderná, čiže nenadväzujúca na tradície l'udového stavitel'stva Hontu. Určitá spätost' s l'udovými tradíciami Hrušovčanov tu predsa len je. Domy s rovnou strechou sa vobci takmer nevyskytujú, čo sa o väčšine slovenských dedín vonkoncom nedá povedat'. Dve z troch obecných bytoviek sú moderné stavby, ale tiež so šikmou strechou. Tretia bytovka je staršia, vznikla adaptáciou domu židovského obchodníka Hessa s krčmou a obchodom na obytnú budovu s bytmi. V legende sme vlastnou značkou vyčlenili domy rómskej osady Kopanička pre svoju špecifičnost'.

Objekty s inou ako obytnou funkciou sú v prevažnej miere moderné, postavené po roku 1970. Sú medzi nimi obecný úrad spojený s kultúrnym domom, amfiteáter, základná škola, obchody, pohostinstvá a požiarna zbrojnica. V obci však nachádzame aj tradičné objekty tohto funkčného typu. Najstarším z nich je kováčska vyhňa $\mathrm{z}$ druhej polovice 19. storočia zrekonštruovaná do pôvodnej podoby. Stará budova školy v strede starého Hrušova bola postavená v roku 1924, v roku 1954 k nej pristavili budovu s tradičným vzhl'adom, ktorá pôvodne slúžila ako kultúrny dom, miestny národný výbor a pošta. V centrálnej časti obce stojí budova pálenice z roku 1938. V Hrušove sa zachovalo aj väčšie množstvo kamenných pivníc vytesané mäkkých tufových pieskov. Tradícia ich budovania siaha až do 16. storočia. Sústred'ujú sa do troch lokalít intravilánu obce. Brada a Brloš (2013) uvádzajú, že ich v Hrušove približne 200. Medzi tradičné stavby $\mathrm{v}$ obci treba započítat' aj rímskokatolícky kostol z roku 1762 a budova fary $\mathrm{z}$ roku 1811. V mape 7 je ešte početná skupina hospodárskych objektov, ktoré sme do nášho výskumu nezahrnuli. Ide o šopy, stodoly, garáže, kurníky, maštale, sklady a podobne.

\section{Záver}

Výsledky detailného terénneho výskumu ukázali, že laznícka krajina v k. ú. obce Hrušov je poznačená iba nízkym stupňom transformácie a zachováva si svoj tradičný autentický vzhl'ad. Väčšina lazníckych usadlostí je udržiavaná aj v prípadoch, ked' nie je trvalo obývaná. Agilnej samospráve obce sa napriek nepriaznivej demografickej štruktúre obyvatel'stva v podstate darí realizovat' revitalizačné projekty, inšpiratívne aj pre iné laznícke obce na Slovensku. 
Príkladom je budovanie novej siete prístupových ciest k lazníckym usadlostiam, čo zvýšilo záujem novousadlíkov kupovat' alebo prenajímat' nehnutel'nosti mimo intravilán obce a využívat' ich nielen na rekreačné účely. Vo väčšine prípadoch ide o pozitívne aktivity korešpondujúce so zásadami trvalo udržatel'ného rozvoja vidieka. Pozitívnymi aktivitami sú, napríklad, vybudovanie environmentálneho centra a autentické rekonštrukcie pôvodných lazníckych usadlostí. Zachovanie prevažne tradičnej zástavby sme zaznamenali aj $\mathrm{v}$ intraviláne obce, ktorej historické jadro $\mathrm{s}$ výraznou prevahou tradičných l'udových stavieb by mohlo byt' vyhlásené za pamiatkovú zónu l’udovej architektúry. Výsledky prezentovaného výskumu by túto ambíciu mohli podporit'. Kritérium pomerne mladého veku zástavby by nemalo byt' relevantné.

\section{Pod'akovanie}

Príspevok bol spracovaný v rámci riešenia projektu VEGA č. 2/0013/18 Hodnotenie transformácie prírodnej a sociálno-kultúrnej diverzity kultúrnej krajiny Slovenska (na priklade vybraných území).

\section{Literatúra}

BAKÁCS, I. 1971. Hont vármegye Mohács elött. Budapešt': Akadémiai Kiadó, 1971. $482 \mathrm{~s}$.

BOTÍK, J. 1967. K problematike rodinného života v oblasti Krupinskej vrchoviny. In Slovenský národopis. roč. 15, č. 3, s. 386-416.

BOTÍK, J. 1980. Dvojrezidenčnost' ako dôsledok lazového osídlenia. In Slovenský národopis. roč. 28 , č. 1 , s. 78-83.

BOTÍK, J. 2014. Hrušov a Hrušovčania. Hrušov: Obec Hrušov, 200 s.

BRADA, P. - BRLOŠ, J. 2013. Tradičné stavitel'stvo v Hrušove. Hrušov: Obec Hrušov, 2013. $288 \mathrm{~s}$.

BRADA, P. - ZRNÍKOVÁ, K. - BRLOŠ, J. 2014. Rolníctvo v Hrušove. Hrušov: Obec Hrušov, 2014. $334 \mathrm{~s}$.

FORMAN, R. T. T. - GODRON, M. 1993. Krajinná ekologie. Praha: Academia, 1993. $583 \mathrm{~s}$.

HANUŠIN, J. - LACIKA, J. 2017. Transformácia historickej kultúrnej krajiny s rozptýleným osídlením (na príklade obce Hrušov, okres Vel'ký Krtíš). In Ira, V., Hanušin, J. (eds) Premeny a ochrana historickej kultúrnej krajiny na Slovensku. Geographia Slovaca 33. Bratislava: GÚ SAV, s. 85-120.

HANUŠIN, J. - LACIKA, J. 2018. Vybrané environmentálne súvislosti zmien historickej lazníckej krajiny (na príklade obce Hrušov, okres Vel'ký Krtíš). In Geografický časopis. roč. 70, č. 1, s. 57-77.

HROMÁDKA, J. 1943. Všeobecný zemepis Slovenska. In Novák, L. (ed.) Slovenská vlastiveda, 1. Bratislava: SAVU, s. 81-332. 
HUBA, M. 1989. O niektorých otázkach genézy a súčasného stavu kopaničiarskeho osídlenia na území Slovenskej socialistickej republiky. In Geografický časopis. roč. 41, č. 2, s. 138-155.

HUBA, M. 1990. O perspektívach kopaničiarskeho osídlenia a kopaničiarskej krajiny na území Slovenskej republiky. In Geografický časopis. roč. 42, č. 2, s. 113-130.

HUBA, M. 1997. Kopaničiarske osídlenie, životné prostredie a trvalo udržatel'ný spôsob existencie. In Životné prostredie. roč. 31, č. 2, s. 61-66.

JANŠÁK, Š. 1929. Príspevok k štúdiu osídlenia Slovenska, Obce a kopanice. In Sborník muzeálnej slovenskej spoločnosti. roč. 23, č. 3-4, s. 93-111.

KOVÁČOVÁ B. a kol. 1990. ÚPN - Z Hrušov, Laznícke osídlenie. Sprievodná správa (manuskript). Banská Bystrica: Stavoprojekt š. p., 1990. 85 s.

LACIKA, J. 2009. Ranný novovek, Premeny krajiny. In Kršák, P. (ed.) Slovensko, Ottov historický atlas. Bratislava: Ottovo nakladatelství, 2009. s. 248-249.

LACIKA, J. - HANUŠIN, J. 2018. Natural aspects of the development of the landscape with dispersed settlement (example of the Hrušov village cadastral area). In Useful geography: Transfer from research to practice : Proceedings of 25th Central European Conference. Brno: Masaryk university, pp. 187-202.

LAUKO, V. 1985. Vývoj a transformácia kopaničiarskeho osídlenia Myjavskej pahorkatiny. In Acta Facultatis Rerum Naturalium Universitalis Comenianae, Geographica. roč. 25, s. 35-52.

LUKNIŠ, M. 1980. Kopaničiarske osídlenie v Gemeri. In Slovenský národopis. roč. 28 , č. 1 , s. $41-50$.

NÁRODNÝ GEOPORTÁL SR 2014. Historické mapy vojenských mapovaní. SAŽP 2014. Dostupné na: http://geoportal.gov.sk/sk/map?permalink=85fee947 30605ec9aad47e531552ea54

OMASTA, Š. 2011. Rozptýlené vidiecke osídlenie - socioekonomické a historické aspekty. In Životné prostredie. roč. 45, č. 1, s. 43-47.

PETROVIČ, F. 2005. Vývoj krajiny v oblasti štálového osidlenia Pohronského Inovca a Tribeča. Bratislava: Ústav krajinnej ekológie SAV, 2005. $209 \mathrm{~s}$.

PETROVIČ, F. 2006. Changes of the landscape with dispersed settlement. In Ekológia (Bratislava). roč. 25, Supplement 1, s. 201-211.

PRELOVSKÁ, D. 1987. Kopanice v Nitrianskej stolici v polovici 18. storočia. In Agrikultúra. roč. 21, s. 41-65.

SPIŠIAK, P. 1998. Vývoj obyvatel'stva v kopaničiarskom osídlení Slovenska. In Geografické informácie. roč. 5, s. 18-25.

ŠVECOVÁ, S. 1979. Názvoslovie lazového osídlenia v Honte. In Slovenský národopis. roč. 27 , č. 1 , s. 25-49.

ŠVECOVÁ, S. 1980. Význam komasácie pre vývoj lazového osídlenia v Honte. In Slovenský národopis. roč. 28, č. 1, s. 35-40.

ŠVECOVÁ, S. 1984. Lazy v 19. a 20. storočí. Vývoj rolníckych chotárnych sídiel v oblasti Krupinskej planiny. Praha: Univerzita Karlova, 1984. 
ŠVECOVÁ, S. 1988. Lazy a lazníci. In Botík, J. (ed.) Hont - tradicie l’udovej kultúry. Martin: Osveta, 1988. s. 392-425.

VEREŠÍK, J. 1974. Vidiecka sídla. Slovensko - Lud 3, 1. čast'. Bratislava: Obzor, 1974. s. 463-521.

ZRNÍKOVÁ, K. - HRČKOVÁ, I. 2012. Výskum historických krajinných štruktúr a och stupňa zachovalosti pre potreby starostlivosti o krajinu vo vybraných katastrálnych územiach Hriňová a Hrušov. Krajinno-ekologická štúdia. Zvolen: Technická univerzita vo Zvolene, 2012.

\section{SELECTED GEOGRAPHICAL ASPECTS OF THE LANDSCAPE WITH SCATTERED SETTLEMENT (ON THE EXAMPLE OF THE VILLAGE HRUŠOV)}

\section{Summary}

The landscape with scattered settlement has been important part of the various landscape picture of Slovakia. According to Verešík (1974) this type of the cultural landscape covers almost one tenth of whole Slovakia territory. The villages with scattered settlements occur predominantly in the montane parts of the Slovak Carpathians characterized by hindered live condition of the inhabitants closely connected to nature. Therefore, these low developed regions have been distinguished by very sparse settlement. They have been distinguished by worse demographic development caused by massive moving of the inhabitants in productive age out from scattered settlements. They have moved not only to compact village, bud dominantly out of region. Therefore low developed regions with scattered settlements do not dispose by inner human, material and financial sources for management of the landscape with high operating costs. The local governments of these regions need helps from outside for preparing and realisation of the project of revitalisation of the landscape with scattered settlement. This contribution has been created as a part of the scientific project focused on the geographical research of the specific type of the cultural landscape characterized by scattered settlement in the cadastral area of the village Hrušov (district of Vel'ký Krtís) in southern part of the Central Slovakia. We have used for our research good co-operation with agile local government. In spite of contrarious demographic development the people managed this village have realized several good project improving quality of live for inhabitants of the scattered settlements.

There are approximately 200 scattered settlements in the territory of the cadastral area of the village Hrušov covered 2331 hectares. According to results our very detailed research and field mapping we can identified very close influence of the properties of the natural landscape to areal composition of the scattered settlements (map 5). Their localisation prefers more flat landform of the plateaus on southern border of non-karst Krupinská Planina Mts. We have identified some 
linear patterns of the settlements composition. They are caused by the relief properties. There are 3 types of linearity in different geomorphological positions: on the plateau-like ridge, in the valley and on the edge of the plateau. The map 5 shows, the scattered settlements dominantly concentrate to clumps, but there are several isolated scattered settlements. The field mapping has showed that the Hrušov's cultural landscape with scattered settlement has been transformed very slightly, therefore the actual landscape picture is very original and authentic. We have recognized very similar stage of traditional shape of landscape inside of the village of Hrušov (map 7). Our detailed fieldwork research in the residential area has showed its modern transformation was very slightly too, therefore the historical centre of Hrušov is very authentic, with strong prevailing of the traditional countryside type of buildings. It is very good protected compact segment of the historical cultural landscape. Our research results has advanced perspective creation of the conservation area of the folk architecture.

\section{Doc. RNDr. Ján Lacika, CSc.}

Katedra geografie a regionálneho rozvoja FPV UKF v Nitre

Trieda A. Hlinku 1, 94974 Nitra

E-mail: jlacika@ukf.sk

RNDr. Ján Hanušin, CSc.

Geografický ústav SAV

Štefánikova 49, 81473 Bratislava

E-mail: hanusin@savba.sk 